\title{
Character Education through the Constructivist Design of Islamic Education Subject at Elementary School Pembangunan Jaya II in Gedangan Sidoarjo
}

\author{
Evi Fatimatur Rusydiyah \\ Department of Islamic Education, Faculty of Islamic Eductation and Teacher Training \\ UIN Sunan Ampel Surabaya, Indonesia \\ E-mail: evi fatimatur@yahoo.com \\ DOI: http://dx.doi.org/10.15548/jt.v21i3.108
}

\begin{abstract}
The objective of this study are (1) to determine the meaning of character education in the elementary school of Pembangunan Jaya II of Gedangan Sidoarjo, (2) to identify how the planning of character education through constructivist design on the Islamic education subjects in the elementary school of Pembangunan Jaya II of Gedangan Sidoarjo. Observation, in-depth interviews and documentation analysis were used in this study. The finding showed that: (1) elementary school Pembangunan Jaya II in Gedangan Sidoarjo has developed character education. The character education that is developed is fond of learning character, creative character, independent character and noble, (2) constructivist design that is developed by SD Pembangunan Jaya II Gedangan Sidoarjo has a component in accordance with the constructivist theory, namely, engage, explore, explain, extend, and evaluate. By the application of habituation based on the constructivist design make the students to have the attitude of eager to learn, creative, independent, and noble character in accordance with the main purpose of the school.
\end{abstract}

Keywords: Education, character education, constructivist designs

\section{INTRODUCTION}

The establishment of competitive generation and superior nation is not an easy matter in the life of nation. It takes the role of the community and all the layers to support it. Education is one of the programs that can help these objectives. For Indonesia nowdays, the character education also means doing the effort earnestly, systematically and continuing to awaken and strengthen the awareness and confidence of all Indonesian people that there will be no better future without build and strengthen the character of Indonesian nation.

In other words, there is no better future that can be realized without honesty, without increasing the self-discipline, without persistence, without high spirit of learning, without developing sense of responsibility, without fostering the unity in the middle of diversity, without the spirit of contributing the improvement together, and without a sense of confidence and optimism. Theodore Roosevelt said: "To educate a person in mind and not in morals is to educate a menace to society" ${ }^{2}$.

Character education is a long-term educational project because it is appropriate to the meaning of his origin; character is the process to carve the values that are considered to be well into the hearts of students. Therefore, it will take a long time to be able to change it. Character has the similarities with the moral, morals, norms or character because it is directly driven by the brain. A person's character can be shown by how he/she acts when he/she knew no one who saw it. This attitude will be automatic because it is directly driven by the brains.

The quality of learning based on constructivism provides the opportunity for students to express explicitly the ideas of using language students themselves, sharing the ideas with his friend, and encourage the students to give the explanation of his ideas, as well as provide the experiences that related to the idea 
that has been owned by the students or designing of activities are appropriate to the early idea of the students so that they expand their knowledge of the phenomenon and have the opportunity to set the phenomenon, so that the students are encouraged to differentiate and integrate the idea of a phenomenon that challenges the students.

Another strength in the constructivist learning is contructivism learning to give students the opportunity to think about his experience. It can encourage students to think creatively, imaginatively, encouraging reflection of the models and theories, introducing the ideas at the right time, giving students the chance to try the new ideas, in order that the students are encouraged to acquaire confidence in using a variety of contexts, both of which have been known and new. Finally motivate the students to use a variety of strategies to learn, think the changes of their ideas after realizing their progress and give the students the opportunity to identify the changes of their ideas.

Focus on research problems are (1) how is the meaning of character education in the elementary school of Pembangunan Jaya II of Gedangan Sidoarjo?, (2) how is the character education planning through constructivist design on the subjects of Islamic education in the elementary school of Pembangunan Jaya II of Gedangan Sidoarjo?. While, the objective of this study are (1) to know what is the meaning of character education in the elementary school of Pembangunan Jaya II of Gedangan Sidoarjo, (2) to know what is the meaning of constructivist design in the elementary school of Pembangunan Jaya II of Gedangan Sidoarjo, (3) to know how the planning of character education through constructivist design on the Islamic education subjects in the elementary school of Pembangunan Jaya II of Gedangan Sidoarjo.

The previous research related to this constructivist learning, it has been done by other researchers. These studies can be classified as follows (1) Implications of contextual teaching and learning in the formation of character in the learning of Islamic education at SMAN I Pasuruan (Research, H.M. Saing Abdullah, 2010), (2) Application constructivist approach to learning PAI in improving students' creativity of SMPN I Singosari Malang, (Qomariyah, 2006), (3) Application of constructivist model to improve the science learning outcomes (Hapsari, 2010).

\section{METHOD}

This study uses a qualitative approach with descriptive research. The types of data are statements that are submitted by the researcher in accordance with a set of research questions that are proposed in this study, and the documentation that is as reinforcement of the data is obtained by the statement of the research subjects. While, the data collection techniques that is used in this study is observation, in-depth interviews, and documentation analysis. Observations are used for the reasons to optimize the ability of researchers in terms of motives, beliefs, attention, unconscious behavior, and habits. This type of observation is the observation that is not participate, it means that the researcher is as the fully observer because the researcher is not eligible to enter into the private area of the subject.

Data analysis is the effort to search for systematically and record the notes of observation, interviews and others, to improve the understanding of the researcher about the case that is investigated and to present it as findings to others ${ }^{4}$. The steps that are taken in the data analysis during data collection are namely: cheking, organizing, checking findings of validity, the extension presence of the researcher, deepened observation, and triangulation. The stages of the research that is pursued by researcher are the researcher categorizes three phases: pre-field stage, field stage and data analysis stage. 


\section{RESEARCH FINDINGS}

Character Education in the Elementary School of Pembangunan Jaya Ii in Gedangan Sidoarjo

Character education for the elementary school of Pembangunan Jaya II of Gedangan Sidoarjo is not strange things. Since the operation of this school in the academic year of 2005-2006, the concept of character education is characteristic in the implementation of learning. Characters that are formed through the learning process are (1) the character of studied hard which is implemented through the enthusiasm personality, curiosity, critical, logical, objective, and discipline; (2) creative character which is implemented through sensitive personality, imaginative, innovative, analytical, openminded;

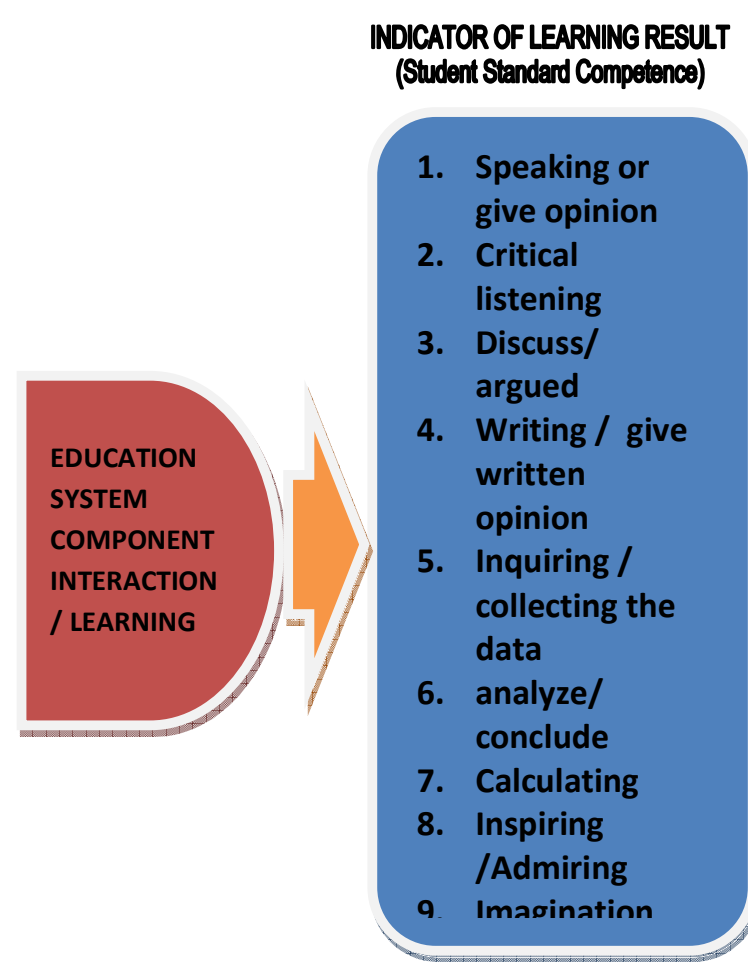

(3) independent character which is implemented through dare to take the risk, responsibility, initiative, diligence or resilient, and confidence; and (4) attitude character which is implemented through the character of honest, fair, ethical, cooperation, compassion, and faith or piety.

Achieving the character of education in the elementary school of Pembangunan Jaya II of Gedangan Sidoarjo can be explained through the following flow.

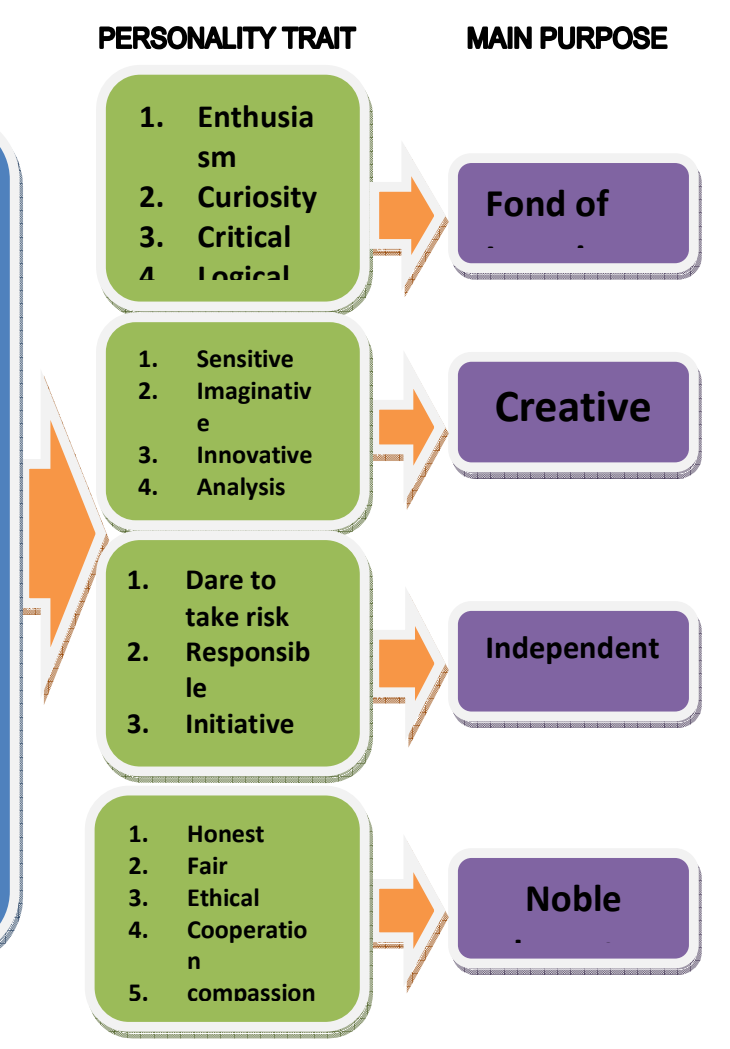

Figure 1. Character of Education 
The characters value that are developed above are analyzed based on the characters value that are formulated by the National Research and Development Centre Ministry of National Curriculum is as follows:

\section{Religious}

Religious character that is developed by the National Research and Development Centre Ministry of Education curriculum is in line with the character value that was developed by the SD Pembangunan Jaya II Gedangan Sidoarjo is the character of faith and piety with the main purpose of the students has attitude character. The main purpose of the character of faith and piety is in line with the value of a religious character that has attitude and submissive behavior in carrying out the teachings of their religion, the practice of religion tolerant of others, and living in harmony with other faiths. The elementary school of Pembangunan Jaya II of Gedangan Sidoarjo has multicultural characteristics. One of the school programs is to provide the opportunities for the students to practice their religion in accordance with their respective worship. Multicultural education can also be seen from the several programs commemoration religious holidays that are celebrated by involving the whole school stakeholders.

\section{Honest}

Honest character that is developed by the National Research and Development Centre Ministry of National Curriculum is also in line with the character value that was developed by the SD Pembangunan Jaya II Gedangan Sidoarjo are honest that become main purpose in the formation of good moral character. Honest is the behavior based on the effort to make himself as a person who always believed in words, actions, and work.

\section{Tolerance}

The value of tolerance character is not explicitly found in the characters values in the SD Pembangunan Jaya II Gedangan Sidoarjo, but the equivalent of the word of tolerance can be found through word of compassion, ethical,

and fair. According to the researcher's analysis of compassion, ethical, and fair is a part that is not separately from tolerance value. It is because tolerance is an attitude and actions which respect the differences of religion, race, ethnicity, opinions, attitudes, and actions of others who are different from themselves. SD Pembangunan Jaya II Gedangan Sidoarjo has attention to the value of tolerance characters in each activity.

\section{Discipline}

The value of disciplinary character was found in the values of the characters in SD Pembangunan Jaya II Gedangan Sidoarjo. The value of disciplinary character has a major goal in the learning. Discipline of behavior will affect the students to learn. The formation of this discipline character is friendly to the students. The teacher in the learning process PAI found that the teachers are friendly to the students; from the sample interviewed, the students said that they were happy with the teachers of PAI. There are many reasons that they said, such as The way of the teachers teach the students happily and establish the discipline with knowing the importance of Islamic Education in everyday life. The value of this discipline character is act that shows the behaviour of orderly and obedient in the various rules and regulations.

\section{Work Hard}

Hard work is not found explicitly in the characters value in SD Pembangunan Jaya II Gedangan Sidoarjo. The word that is found as a synonym of work hard is diligent or resilient. The value of diligent or resilient character is to achieve the main goals of independent. Independence of the students becomes important as the product of education. The character is trained or socialized in the subject of Islamic education through the assignments structured or unstructured to be done by the students. Working hard or diligently is the act that shows the behavior of an orderly and obedient to the various rules and regulations.

\section{Creative}


The value of creative character is found in the character value in SD Pembangunan Jaya II Gedangan Sidoarjo with imaginative, innovative, and initiative. These three characters values have the same spirit in delivering the students to think and do something to generate a way or the new result of something that has been owned. The value of imaginative and innovative character has a primary purpose of creative, while the value of the initiative character has the main purpose of independent. The formation of character has the main purpose of creative and independent primary. It has also been carried out by the Islamic Religious education teachers (PAI). Teachers in carrying out their duties as teachers facilitate the students in tasks creatively and independently. For example, there is the display of student work in the class and the teacher gives the task independently in the learning process.

\section{Independent}

For SD Pembbangunan Jaya II Gedangan Sidoarjo, the independent is the main purpose of forming the desired character that is wanted by the elementary school curriculum. Independent that is as creative has personality dared to take the risk, responsibility, initiative, diligence or resilient, and confident. Independent is the attitudes and behaviors that are not easy to depend on others to complete tasks.

\section{Democratic}

Explicitly democratic value is not found in the value of the character in SD Pembangunan Jaya II Gedangan Sidoarjo, but the synonym from the list character value that is arranged by the school can be found through the character value of fair, ethical, and cooperation. These third character values have primary purpose to deliver the students of noble character. Democratic is the way to think, have attitude, and act that is judging the same rights and obligations to himself and others.

\section{Curiosity}

This character value that is found in the document character of SD Pembangunan Jaya II
Gedangan Sidoarjo in English is curiosity. This character has the main purpose eager to learn. Curiosity is the attitude and actionsthat are always working to know more depth and breadth from the thing that is learned, seen, and heard.

\section{The Spirit of National}

The fourth mission of SD Pembangunan Jaya II Gedangan Sidoarjo is a source of pride Pembangunan Jaya group as public school that values diversity / multicultural, tolerant, and dignified. The mission gives the meaning to the civilization of Indonesia which culturally diverse. National spirit appears in the mission, as a nation of Indonesia's diverse characteristics, so that the students need to be equipped national spirit that is multicultural, tolerant and dignified. The national spirit is a way of thinking, acting, and has a conception that puts the important of nation and country on the selfinterest and group.

\section{Love Homeland}

As the national spirit, love of homeland character is also based on the school's fourth vision, it becomes pride the group Pembangunan Jaya as a public school that values diversity / multicultural, tolerant, and dignified. This form of love homeland is in the form of culture day program. The program is implemented 1 year at once. The program is in the form of the introduction of Indonesian culture with diverse characteristics through the carnival activities and performing arts. The way to think, act, and has a conception that puts the important nation and country on self-interest and group.

\section{Rewarding Achievement}

Elementary school Pembangunan Jaya II Gedangan Sidoarjo is not mention explicitly about rewarding achievement character, but it has open minded character. It is character that has a creative purpose. Likewise, there is the character of compassion as the purpose of noble character. The combination of two main objectives of the study will produce the students 
who can appreciate the achievement. Appreciating achievement is one form of creative attitude of the students to see a success. Appreciating achievements is the attitude and action that encourage him to produce something that is useful for society, and acknowledge, and respect for other people's success.

\section{Friendly / Communicative}

SD Pembangunan Jaya II Gedangan Sidoarjo is not explicitly to have friends or communicative values. But there is compassionate in the list of the character that has the primary purpose of noble character. According to researcher, friend has equivalent with compassion. Friend/ Communicative is the act that encourage him to produce something useful for society, and acknowledge, and respect for other people's success.

\section{Love and Peace}

Peace-loving character value can be seen in a fair honest and ethical. These three characters have a goal of noble character. Peace-loving character in SD Pembanguan Jaya also appears in the vision and mission of this school. The mission becomes a source of pride Pembangunan Jaya Group as a public school that values the diversity or multicultural, tolerant, and dignified. Peace-loving character is the attitude and actions that encourage him to produce something that is useful for society, acknowledge, and respect for other people's success. This character is also grown in the social life of the class. At each grade in SD Pembangunan Jaya II looks the multicultural spirit. The students who study in this school are not only from the elements of Java, but also Chinese, Arabic, and other areas in Indonesia. This is because SD is located in the elite residential area.

\section{Fond of Reading}

Fond of reading characters can be seen in SD Pembangunan Jaya II Gedangan as the main goal of education. Fond of reading is as well as the fond of learning that has an enthusiastic character, curiosity, critical, logical, objective, and disciplined. Learning environment in SD shows this activity with a variety of patterns. The assignment in the form of searching through the internet and embrance from the result of his browsing. Then, it is summarized to be a product that the result is presented. Another pattern that is found is the learners that are asked to summarize the material in the book, then the next meeting presented. This activity is the habit to supply the time to read a variety of literature that gives virtue for him.

\section{Environmental Care}

Environmental care character can be seen through the main goal in SD Pembangunan Jaya II Gedangan, It is through the purpose of noble character that has the characteristics of an honest, fair, ethical, cooperation, compassion, and faith / piety. Outbound activity is the activity that trains the students to care for the environment. This activity is carried out once a year. This school has a program of care for the environment that is to plant 1,000 trees in 2013 . This activity led to the students to care about the greening phenomenon in Surabaya and surrounding areas including Sidoarjo as industry town. The word industry needs to be supplemented greening that has function to suck carbon dioxide as a result of plant waste that pollutes the air. The environmental care can also be seen in the the learning process through the attitudes and actions which seeks to prevent damage to the surrounding natural environment, and develop the efforts to repair the environmental damage that has occurred.

\section{Social Care}

SD Pembangunan Jaya II Gedangan Sidoarjo trains the children for social care in some activities. These activities can be seen through the Idul Qurban activities. In this activity, the students are invited to share the sacrificial goat to the poor society. Other activity that can develop social awareness is not to be permitted of any low-grade students in the name only to the class brothers. But it must be added with big brother. The program trains students to respect the seniors in real life. It will train the students to care about the surrounding, 
it develops the respectful manners. Social care is the attitude and action that always want to help other people and communities that needed.

\section{Responsibility}

SD Pembangunan Jaya II Gedangan Sidoarjo develop the character of responsibility which has main goal is independence. This character familiarized through the learning process that gives the students assignment either individually or in groups. Responsibility is the attitude and behavior of a person to perform his duties, he should do, to himself, society, the environment (natural, social and cultural), country and God Almighty.

Planning of Character Education Through Constructivistic Design of Islamic Education Subjects in SD Pemba-Ngunan Jaya Ii Gedangan Sidoarjo

In designing constructivist-based learning of Islamic education at the school in this research is involved five steps. They are engage, explore, explain, extend / elaborate and evaluate. Analysis of constructivist design is seen through how the Islamic education teacher in SD Pembangunan Jaya II of lesson plan (RPP). The result of the analysis of RPP with bonding theory (constructivist design) can be described as follows.

First, engage (drawing attention, curiosity, engagement), where the learners access the prior knowledge and help them to involve in the new concept of reading, asking questions, doing demonstration, or doing some short activity that promote curiosity and lead to the beginning knowledge. In the second RPP of PAI teacher illustrates the process of this engage. This process is carried out in accordance with the characteristics of their students. Grade 1 to grade 6 has different characteristics. In RPP also visible the difference treat, for example lesson plan for grade 5 that its students more active, then engage that was done more do many questions and demonstrations. This is different from the handling of other classes, such as grade 6 that is quieter. Therefore, engage for grade 6 can be more varied, likewise other classes.
Second, explore (exploration), where the learners work in collaborative team to complete the activities that help them to use prior knowledge to produce the ideas, explore the questions and possibilities of answers, design and conduct of inquiry. In RPP, the teacher of PAI in SD Pembangunan Jaya II Gedangan Sidoarjo also appears how the teacher explores the waysof the teachers form a team by asking the questions in the inquiry learning, the students are asked to find independent knowledge through collaborative work. This collaborative work is important for the students as theirlife provision in the future. Because as the adults, they will work and the place of work need a collaborative inter-team, so that learning is designed by using exploration as in SD Pembangunan Jaya II Gedangan Sidoarjo. It is actually to equip the students to do team-based work early.

Third, explain, where the learners are given the opportunity to explain their understanding of the concepts being studied. They can explain to create presentations, sharing ideas with others, reviewing the explanation of knowledge and compare it with their own understanding, and or listen to the explanation of the learners that help them toward a deeper understanding. This activity can also be seen in each teacher's RPP. Learning activities give the students chance to explain about what was found in front of their friends. While another friend who did not explain listening and asking questions or responding toward the finding friends who do the explanation. This activity takes place in an interactive and interesting, because every the students have high confidence in expressing his ideas.

Fourth, extend / elaborate, where the learners itemize or deepen their understanding on a concept with additional activities, such as doing the activity, project, or idea earlier, or activities that require the application of concepts. The focus at this stage is to add breadth and depth of their understanding. The activities of extend/ elaborate this is done after they do sharing in their groups, then they write 
back what was discussed in the certain pages (Activity Sheet). However, they form in a picture posted on the classroom wall as a result of student work. These activities train confidence and give effect to the pride of the recognition of their work.

Fifth, evaluate, where the teachers encourage the students to access how much understanding and their ability to a concept, and give the learners the opportunity to evaluate progress towards the achievement of learners expected goals. In this activity the two of PAI teacher are doing well. Before the study ended, they were both doing the assessment. The assessment that is done before the learning process ended is the core of classroom-based assessment. The assessment is not only do in the cognitive achievement, but also in the learning process. During this learning process that assessed the attitudes and skills that have been possessed by the students.

Islamic Education in the SD Pembangunan Jaya II Gedangan Sidoarjo has the character aspect that is focused on the main purpose of education through discussing / arguing, analyzing / concluding, appreciating / respect, and reading. These four indicators of learning outcomes have a major goal in education. Those are eager to learn, creative, independent, and noble character.

Design of constructivist learning in the lesson plan of Islamic religious teacher looks through constructivist design, it is namely how the students become active (student centered). Constructivist learning model application in the PAI subjects of SD Pembangunan Jaya II in Gedangan Sidoarjo begins with the reading prayers before learning. By reading habit of prayer is expected that the students can build a personality for love, listen and recite prayers and able to develop the religious attitudes in everyday life. Then, the teacher ask the attendace list to student.

Then, the teacher gives a brief explanation of the material to be delivered. The method that will be used by the teacher in the learning PAI is based activity methods. It is by holding discussions, which have been shared by several groups. Then, debriefing of the students and the teachers or the students and the students better understand the material being studied and analyzed in accordance with their mindset. So that the output of this learning student can apply in the real world.

The procedures or steps that are undertaken in this study, there are several stages. It is appropriate with five steps of constructivist learning in the early learning of the teachers that do apperception by asking a few things about the students' knowledge of the material that will be presented. Then, the teachers provide the opportunities for students to explore. Then, the teacher divides the students into groups to discuss the material that has been given. After that, the teacher gives the students individual tasks such as filling the material that has been presented by the teacher and do the homework to determine their own understanding of the analysis results.

At the next meeting, each student is given the opportunity to present his findings. Where explain the material at the previous meeting and presented his findings in the field. Here the students have sources to analyze the material. The source can be taken from the Internet; books are in the library, books that are studied by students or opinions of figures. In this study that is very interesting is when each student describes his analysis of findings that is obtained in some of the internet, read books or opinions of some of the figures.

The character of learning process through the constructivist design is able to deliver on the formation of the character to its students comprehensively, because the formation of this character is done in the learning process, and it is controled through the learning evaluation that systematically included in the student report cards. The best of constructivist learning in this school is also done programmatically by the school. Both activities are academic and nonacademic form that is extracurricular activities that foster self-confidence of students in socializing with the community. 


\section{CONCLUSION}

1. Elementary school Pembangunan Jaya II in Gedangan Sidoarjo has developed character education. The character education that is developed is (1) fond of learning character that is implemented through the personality traits of enthusiasm, curiosity, critical, logical, objective, and discipline; (2) creative character which is implemented through personality traitsof sensitive, imaginative, innovative, analytical, openminded; (3) independent character that is implemented through dare to take the risk, responsibility, initiative, diligence or resilient, and confidence; and (4) noble character is implemented through the character of an honest, fair, ethical, cooperation, compassion, and faith or piety.

2. Constructivist design that is developed by SD Pembangunan Jaya II Gedangan Sidoarjo has a component in accordance with the constructivist theory, namely, engage, explore, explain, extend, and evaluate. Despite of some RPP have not found in this pattern, but in the learning process found this pattern simultaneously. Planning of education character through constructivist design on the subjects of Islamic education in SD Pembangunan Jaya II has been carried out. By the application of habituation based on the constructivist design make the students to have the attitude of eager to learn, creative, independent, and noble character in accordance with the main purpose of the school.

\section{REFERENCES}

Airasian, P. W., dan Walsh, M. E. (1997). Construction Caoutions. Phi Delta Kaooan, 78 (6).

Alberta, E. (2005). The Heart of Matter: Character and Citizenship Education in Alberta School. Alberta: Alberta Education, Learning and Teaching Resources Branching, Minister of Education.
Al-Ghulayani, M. (1953). Idhah al-Nasihin. Pekalongan: Rajamurah.

Arifin, I. (996). (Ed.). Penelitian Kualitatif Dalam Ilmu-Ilmu Sosial dan Keagamaan. Malang: Kalimasahada Press.

Based Teaching on English Language Learnes Understanding of science in a Middle School Classroom. Unpublished Dissertation. Kansas State University. (Online).(http://krex.kstate.edu/dspace/bitstream2097/301/1/CM atthewSeimars2007.pdfdiakses $30 \quad$ Mei $\underline{2010}$ ).

Berkowitz, M.W. \& Bier, M. C. (2005). What Works in Character Education: A Research-driven Guide for Educators. Washington: Character Education Partnership

Brooks, J.G, \& Brooks, M. (1993). The case for constructivist classrooms.Association for supervision and curriculum development.Alexandria Virginia.

Character Education Partnership. (2003). Character Education Quality Standards. Washington: Character Education Partnership.

Chen. C. (2003). A Constructivist Approach to Teaching: Implications in Teaching Computer Networking, Information Technology, Learning, Performance Journal, Vol 21, No 2: 17-27.

Cholisin. (2004). Konsolidasi Demokrasi melalui Pengembangan Karakter Kewargane-garaan, Jurnal Civics, Vol. 1, No. 1: 14-28.

Cooper. P.A. (2008). Paradigm Shift in Designed Instruction: From Behaviorism to Cognitivism to Constructivism. Educational Tchnology. 33: 1-15. 
Cholewinski, M. (2009). An introduction to Constructivism and Authentic Activity, No. 5, Bulletin Universitas Study Asing Kontemporer Internasional Nagoya, (Online), (http://library.nakanishi.ac.jp/kiyou/11.p df. Retrived on October $25^{\text {th }} 2009$ ).

Dabbel, J. (2007). The 5Es. (Online) (http//www.ncetm.org.uk/blogs/1161, diakses 6 Januari 2010).

Degeng N.S. (1997). Pandangan Behavioristik vs Konstruktivistik: Pemecahan Masalah Belajar Abad XXI. Malang: Paper TEP. Page 12.

Dick, W., Carey, L., \& Carey, J. O. (2001). The Systematic Design of Instruction. Fifth Edition. New York: Longman.

Dewey, J. (1897). My Paedagogic Creed. School Journal, 54: 77-80.

Duffy, T.M., \& Jonassen, D.H., (1992). Constructivism and The Technology of Instruction: A Conversation. Lawrence Erbaum Associates, Publishers Hillsdale, New Jersey.

Doolitle, P. (2000). Constructivism in Science Education Advanced Educational Phsycology Project., (online), http:// www.tandl.vt.edu/acasey/construct.htm 1, Retrieved on Oktober $26^{\text {th }} 2010$.

Gergen, K.J. (1985). The Social Contructionist Movement in Modern Psychology.American Psychologist, 40: 266-275.

Giesen, J. (2001). Constructivisme: A Holistic Approach to Teaching and Learning, (Online), (http://www.nui.edu/facdev/programs/ha ndouts/constructivism.pdf. Retrived on August $10^{\text {th }} 2009$.

Gundogdu, K. (2010). The Effect of Construcivist Instruction on Prospective
Teachers' Attitudes toward Human Right Education.Electronic Journal of Research Educational Phsichology (EJREP), 8(1): 333-352.

Halstead, J. M \& Taylor, M. J. (2000). Learning and Teaching about Values: A Review of Recent Research." Cambridge Journal of Education. Vol. 30 No.2: 158- 167.

Hoover, W.A. (2009). SEDL Letter, The Practice Implications of Constructivism, Vol.IX, No 3: 1-2.

Huitt, W, G. (2009). Constructivism. Educational Phsycology Interactive. Valdosta, GA: Valdosta State University, (Online), (http://www.edpsycinteractive.org/topics lcogsys/construct.html.

Jonanssen, D.H. (1990). Objectivism Versus Constructivism: Do We Need NewPhilosophical Paradigm? ERT \& D, Vol. 29, No. 3:5-14.

Kanselaar,G. (2002). Construktivism and socioconstructivism, (online), (http://edu.fss. uu.nl/medwerkers/gk/files/constructivis m-gk-pdf. Retrieved on January $27^{\text {th }}$ 2010).

Kementrian Pendidikan Nasional Badan Penelitian dan Pengembangan Pusat Kurikulum. (2010). Pengembangan Pendidikan Budaya dan Karakter Bangsa.Kementrian Pendidikan Nasional: Jakarta.

Kerr, D. (1999). Citizenship Education in the Curriculum: An International Review," The School Field. Vol. 10: 3-4.

Kim, J. S., (2005). The Effect of a Constructivist Teaching Aproach on Student Academic Achievment, Selfconcept and Learning Strategies.Asian Pacific Education Review, Vol. 6 (1): 719. 
Lickona, T. (1991). Educating for Character: How Our schools can teach respect and responsibility. New York: Bantam Books.

Lorsbach, A. W. (2002). The Learning Cycle as a Tool for Planning Science Instruction. (Online) (http://coe.ilsu.edu/scienseed/lorsbach/ 2571rcy.htm. Retrieved on January $6^{\text {th }}$ 2010.

Majid, A. \& Andayani, D. (2004). Pendidikan Agama Islam Berbasis Kompetensi, Bandung: Remaja Rosdakarya.

Miami Musium of Science. 2001. Constructivism and the Five E's. (Online), http//miamisci.org/ph/lpintro5e.htm, diakses pada 6 Januari 2010.

Moleong, L.J. (2002). Metodologi Penelitian Kualitatif. Bandung:Remaja Rosdakarya.

Muhadjir, N. (2000). Metodologi Penelitian Kualitatif .Yogyakarta: Reka Serasin.

Muhaimin. (2004). (Ed. 3). Paradigma Pendidikan Islam. Bandung: Remaja Rosdakarya.

Muntholi'ah. (2002). (Ed. 1). Konsep Diri Positif Penunjang Prestasi PAI. Semarang: Gunung Jati.

Narbuko, C \& Achmadi, A. (2002). MetodologiPenelitian. Jakarta: Bumi Aksara.

Renner, J. W., Abraham. M. R., dan Birnie, H.H. (1988). The Necessity of Each Phase of The Learning Cycle in Teaching High School Physics. Journal of Research in Scence Teaching. Vol 25 (1): 39-58.

Resnick, L.B. (1998). Learning in School and Out. Educational Research, 16 (9): 1623-1540.
Richardson, V. (2003). Constructivist Pedagogy. Teacher College Record, 105 (9): 1623-1540.

Roblyer, M. D. (2006). (4 ${ }^{\text {th }}$ Ed.) Integrating Educational Technology into Teaching. Upper Saddle River: Pearson Merril 1 Prentice Hall.

Rusydiyah, E. F. (2008). Pendidikan Karakter: Antara Cita dan Fakta pada Mata Pelajaran Pendidikan Agama Islam. Jakarta: Rineka Cipta.

Saleh, A.R. (2001). Didaktik Pendidikan Agama.Jakarta: Bulan Bintang Press.

Samsuri. (2004). Civic Virtues dalam Pendidikan Moral dan Kewarganegaraan di Indonesia Era Orde Baru. Jurnal Civics, Vol. 1 (2): 1.15.

Samsuri. (2007). Civic Education Berbasis Pendidikan Moral di China.Acta Civicus, Vol. 1 (1): 23-32.

SEDL (Southwest Educational Development Laboratory). (1995). Constructing Knowledge in the Classroom: Building an Understanding of Constructivism. Clasroom Compass. Vol 1 (3): 1-10.

Seefeldt, W. A., dan Foster, E. (2007). Constructifism: A Highly Effective Instructional Strategy, (Online), (http://aaronseefeldt.com/math/construct. pdf. Retrieved 30 Mei 2010.

Seimears, C. M. (2007). An exploratory Case Study: The Impact of Constructivist. New York: Longman.

Sukardjo \& Komaruddin, U. (2009). Landasan Pendidikan; Konsep dan Aplikasinya.Jakarta: Raja Grafindo Persada.

Suparno, P. (1997). Filsafat Konstruktivisme dalam Pendidikan.Yogyakarta: Kanisius. 
Tynjala, P. (1999). Towards Expert Knowledge? A Comparision Between a Constructivist and Traditional LearningEnvironment in the University. International Journal of Educational Research, 31(5): 357-442.

Thoha, C \& Mu'ti, A. (1998). (Ed. 1). PBM-PAI di Sekolah, Eksistensi dan Proses Belajar Mengajar Pendidikan Agama Islam di Sekolah: Sebuah Pengantar. Yogyakarta: Pustaka Pelajar.

Undang-Undang No. 20 Tahun 2003. (2003). Sistem Pendidikan Nasional, Jogjakarta: Media Wacana.

Voos. J., Wiley.J. \& Carretero, M. (1995). Acquiring Intelktuals Skills.Annual Review of Psychology, 46 (1) :155-88 .

Von Glasserfeld, E. (1989). Knowing Without Metaphysics: Aspek of the Radical Constructifist Positions. In F. Steir (Ed.), Research and Reflexitivity: Toward a cybernetic/social Constructivist Way of Knowing. London: Sage.

Vrasidas, C. (2000). Constructivism Versus Objectifism: Implication for Interaction, Cours Designe, and Evaluation in Distance Education. International Journal of Educational telecommunications, 6 (4): 339-362.

Williams, M. M. (2000). Models of Character Education: Perspectives and Developmental Issues.The Journal of Humanistic Counseling, Education and Development. Vol. 39 (1): 32-40.

Yager, R.E. (1991). The Constructivist learning Model: toward Real Reform in Science Education. The Science Teacher, 56 (6), 52-57.

Zarei, G. R. \& Esfandiari, M. A. 2008. The Effect Constructist vs Conventional Teaching on Reading Comprehension,
Medwell Journal, The Socikal Science, 3 (8): 606-610.

Zurayq, M.M. (2003). Sukses Mendidik Anak. (Translation). Badruddin. Jakarta: Serambi. 